\title{
Fumonisins B1 + B2 change the expression of genes in apoptosis balance in Nile tilapia fingerlings
}

\author{
Stefânia C. Claudino-Silva ${ }^{\mathrm{a}}$, Bruno Lala ${ }^{\mathrm{b}, *}$, Natália H.A.P. Mora ${ }^{\mathrm{c}}$, Christiano R. Schamber ${ }^{\mathrm{d}}$, \\ Carlos S. Nascimento ${ }^{\mathrm{e}}$, Vinícius V. Pereira ${ }^{\mathrm{f}}$, Dayne L. Hedler ${ }^{\mathrm{g}}$, Eliane Gasparino ${ }^{\mathrm{h}}$ \\ ${ }^{a}$ Department of Veterinary Science, UNICESUMAR, University Center of Maringá, Maringá, Brazil \\ ${ }^{\mathrm{b}}$ Department of Animal Science, UNESP, São Paulo State University, College of Veterinary Medicine and Animal Sciences, Botucatu, Brazil \\ ${ }^{c}$ Department of Animal Science, Faculdades Unidas do Vale do Araguaia, Barra do Garças, Brazil \\ d Department of Pharmacology and Therapeutics, UEM, State University of Maringá, Maringá, Brazil \\ ${ }^{\mathrm{e}}$ Department of Animal Science, UFS, Federal University of Sergipe, Brazil \\ ${ }^{\mathrm{f}}$ Department of Engineering, Faculdade Pitágoras, Divinópolis, Brazil \\ ${ }^{g}$ Department of Veterinary Science, UNICESUMAR, PROBIC Scholarship, Maringá, Brazil \\ h Department of Animal Science, UEM, State University of Maringá, Maringá, Brazil
}

\section{A R T I C L E I N F O}

\section{Keywords:}

Fumonisin

Gene expression

Mycotoxin

Oreochromis niloticus

\begin{abstract}
A B S T R A C T
In this study, we tested the hypothesis that the ingestion of feed containing fumonisin affects the apoptosis balance in liver cells. Thus, a trial was conducted with Nile tilapia fingerlings (2.64 $\pm 0.06 \mathrm{~g})$ fed diets containing increasing levels of fumonisin (FB) (0-control diet, 20, 40, and $60 \mathrm{mg} / \mathrm{kg}$ ), and expression of caspase7 (CASP7) and sphingosine phosphate lyase (SPL) genes in liver tissue was evaluated at 15 and 30 days of treatment. SPL:CASP7 mRNA ratio was also evaluated. Relative mRNA levels of SPL decreased in tilapia treated with $60 \mathrm{mg} \mathrm{FB} / \mathrm{kg}$ of diet at 15 days $(P<.0001)$, while a significant increase in SPL was detected at the two highest levels of inclusion at 30 days $(P<.0001)$. CASP7 gene expression decreased linearly as fumonisin was added, at 15 days $(P<.0001)$. At 30 days, however, the relative CASP7 mRNA levels were only reduced in the tilapia treated with $60 \mathrm{mg} \mathrm{FB} / \mathrm{kg}$ of diet $(P=.0011)$. The results obtained in this study suggest a direct relationship between SPL and CASP7 expressions, so it can be inferred that as the period of consumption and level of fumonisin are increased, the numerical relationship between SPL:CASP7 mRNA is also increased.
\end{abstract}

\section{Introduction}

Fumonisin is a mycotoxin produced during the secondary metabolism of the fungi Fusarium verticillioides and $F$. proliferatum (Turner et al., 1999). The presence of fumonisin in animal feeds is relatively common, since corn, that should be a natural target of contamination by the mycotoxins, is commonly used as an energy source (Griessler and Encarnação, 2009). It is known that different levels of fumonisin in fish may affect weight gain (Gbore et al., 2010; Tuan et al., 2003; Pepeljnjak et al., 2002; Lumlertdacha et al., 1995), cause hematological disorders (Gbore et al., 2010; Pepeljnjak et al., 2002), neurotoxicity (Kovačić et al., 2009), and change the relative concentrations of sphinganine (Sa) and sphingosine (So) (Goel et al., 1994).

The most widely accepted theory fumonisin's action is that this mycotoxin competes with sphingoid bases Sa and So for the binding site on the ceramide synthase enzyme, resulting in reduction of relative concentrations of ceramide, an increase in the level of free sphingoid bases (Sa and So) and subsequently of sphingosine 1-phosphate (S1P) (Yoo et al., 1992; Wang et al., 1991).

The imbalance between these bases has been identified as the main factor associated with the hepatotoxic effects of fumonisin, and may be associated with changes in levels of caspases, enzymes involved in triggering the cascade of apoptotic events. The role of fumonisins in apoptotic balance has been reported as being controversial - at times they have been identified as pro-apoptotic (Ribeiro et al., 2010; Jones et al., 2001), and at other times as anti-apoptotic (Boppana et al., 2014; Mullen et al., 2012; Bose et al., 1995). In some cases, fumonisins have been identified as inducers of cell-death resistance even after cells have been subjected to stress factors that represent a risk to the organism (Mullen et al., 2011; Biswal et al., 2000).

Levels of ceramide, sphingoid bases, and S1P are directly associated with cell proliferation and apoptosis. Excess Sa and So can be minimized through their bioconversion to S1P (Riley and Voss, 2006). This bioconversion may disrupt the apoptosis balance by generating large

\footnotetext{
* Corresponding author.

E-mail address: brunolala@hotmail.com (B. Lala).
} 


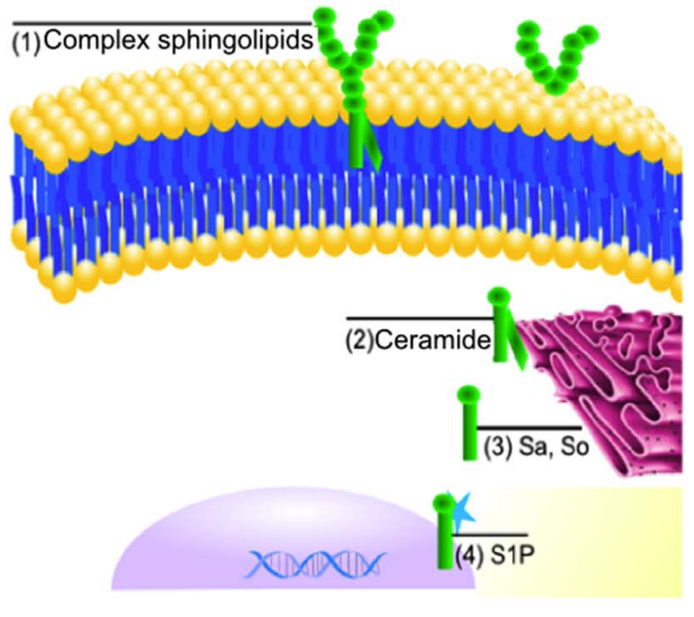

(1) Interactions with extracelular matrix.

Fig. 1. Participation of complex sphingolipids and intermediates in processes related to cell proliferation. Adapted from (Spiegel and Merrill Jr, 1996).

(2) Activation of caspase cascade.

(3) Inibition of protein kinase C.

(4) Proliferation, survival and cytoskeletal

rearrangement.

concentrations of S1P, as this compound is known to be a bioactive metabolite capable of promoting cell proliferation and survival by inhibition of apoptosis (Taha et al., 2006) (Fig. 1).

Therefore, it is likely that fumonisins cause a reduction of ceramide, accumulation of sphinganine, and elevated production of S1P, thereby changing the apoptosis balance. Under normal conditions, homeostasis between sphingosine, sphinganine, and S1P is strictly regulated by activity of several key enzymes, e.g., sphingosine kinase (SPK), sphingosine-1-phosphate phosphatase (S1PP), and sphingosine phosphate lyase (SPL). Sphingosine is phosphorylated by SPK to form S1P. In this stage, S1P may be reverted to sphingosine by S1PP, or even irreversibly generate phosphoethanolamine and hexadecenal by means of SPL action (Taha et al., 2006). The function of phosphoethanolamine is not well known yet; nevertheless, it is believed that the products generated by SPL may be related to an increase in apoptosis by a caspase-3-independent signaling pathway (Ferreira et al., 2013).

In fish, there are no literature reports of fumonisin's action on the molecular mechanisms involved in apoptosis balance such as caspase and SPL gene expression. In this study, we tested the hypothesis that ingestion of feed containing increasing levels of fumonisin mycotoxin affects expression of genes related to apoptosis balance according to period of consumption. Thus, a trial was conducted with Nile tilapia fingerlings fed diets containing different levels of fumonisin to evaluate expression of caspase 7 (CASP7) and sphingosine phosphate lyase (SPL) genes in liver tissue at 15 and 30 days of treatment.

\section{Materials and methods}

\subsection{Ethics statement}

Study protocols were approved by Ethics Committee on Animal Use (CEUA - UniCesumar), Maringá, PR - Brazil. Fishes were anesthetized by immersion in eugenol solution $(350 \mu \mathrm{L} / \mathrm{L})$ prior to sampling and livers were extracted based on the Guide to Care and Use of Laboratory Animals in Brazil.

\subsection{Experimental design and animals}

The experiment was conducted in the laboratory of Aquaculture of the State University of Maringá (UEM), located in Maringá-PR, Brazil, during the entire month of October. A total of 180 sex-reversed male fingerlings of GIFT $\times$ Thai breed group, with an average weight of $2.64 \pm 0.06 \mathrm{~g}$, were used in the experiment. Fishes were distributed into three fiber cement tanks with a useful volume of $870 \mathrm{~L}$ each, an individual water restoration system (15\%/day) and constant aeration provided through porous rock coupled with a central air blower. Four hapa net cages were inserted into each tank, totaling 12 experimental units with four treatments and three replicates. Each hapa net cage had an individual volume of 217.50 and housed 15 fishes, totaling $14.5 \mathrm{~L} /$ fish. Fishes went through an acclimation period of 15 days before the beginning of the experiment.

\subsection{Water quality parameters}

In each cage, temperature was measured twice a day, at 09 h00 and $17 \mathrm{~h} 00$. Dissolved oxygen and $\mathrm{pH}$ were measured in the morning during the entire experimental period using an individual colorimetric kit.

\subsection{Experimental diets}

Four experimental groups were formed: GROUP 1 - control diet, with $0.0 \mathrm{mg}$ of inclusion of $\mathrm{FB} / \mathrm{kg}$ of diet; GROUP $2-20 \mathrm{mg} \mathrm{FB} / \mathrm{kg}$ (16.36 mg $\left.\mathrm{FB}_{1}+3.64 \mathrm{mg} \quad \mathrm{FB}_{2}\right)$; GROUP $3-40 \mathrm{mg} \mathrm{FB} / \mathrm{kg}$ (32.71 mg $\mathrm{FB}_{1}+7.29 \mathrm{mg} \mathrm{FB}_{2}$ ); and GROUP 4-60 $\mathrm{mg}$ of inclusion of $\mathrm{FB} / \mathrm{kg}$ (49.07 mg FB 1 + $10.93 \mathrm{mg} \mathrm{FB} 2$ ).

Four isocaloric (approximately $3000 \mathrm{kcal}$ of digestible energy $/ \mathrm{kg}$ of diet) and isoproteic (approximately 33\% crude protein) diets were formulated, varying only in inclusion of different levels of fumonisin $(\mathrm{B} 1+\mathrm{B} 2)\left(\mathrm{FB}_{1}-6.06 \mathrm{mg}\right.$ toxin/g of medium and $\mathrm{FB}_{2}-1.35 \mathrm{mg}$ toxin $/ \mathrm{g}$ of medium, totaling a concentration of $7.41 \mathrm{mg}$ toxin $/ \mathrm{g}$ of medium) (Table 1). Growth medium was obtained from and evaluated in the Laboratory of Mycotoxicological Analysis (LAMIC) at the Federal University of Santa Maria (UFMS), based on $F$. verticillioides fungus, strain MRC 826.

Feed was pelletized, dried in a forced-air oven at $55^{\circ} \mathrm{C}$ for $48 \mathrm{~h}$, and then crumbled in a manual mill. Particles were classified according to their size ( 1 to $2 \mathrm{~mm}$ ) and concentrations of fumonisin were later confirmed by laboratory analysis (LAMIC). Diets were hand-fed three times a day until apparent satiety of fish.

\subsection{Gene expression}

For analysis of gene expression, livers of six animals from each treatment were collected at 15 and 30 days of experiment to "RNA holder" tubes (BioAgencyBiotecnologia, São Paulo, Brazil) and stored at $-80^{\circ} \mathrm{C}$ until total RNA extraction.

Total RNA was extracted using Trizol $^{\circledR}$ (Invitrogen, Carlsbad CA, USA), according to manufacturer's instructions. All materials used for extraction were pretreated with RNase AWAY $^{\circledR}$ (Invitrogen, Carlsbad, CA, USA), an RNase inhibitor. Tissue was weighed, ground, and mixed with Trizol ( $1 \mathrm{~mL}$ of Trizol per $35 \mathrm{mg}$ of tissue) until it was completely dissociated. After this step, $200 \mathrm{~mL}$ of chloroform was added to the samples, and the mixture was manually homogenized for $1 \mathrm{~min}$. Next, samples were centrifuged for $15 \mathrm{~min}$ at $12,000 \mathrm{rpm}$ and $4{ }^{\circ} \mathrm{C}$, forming 
Table 1

Composition of the experimental diets.

\begin{tabular}{|c|c|c|c|c|}
\hline \multirow[t]{2}{*}{ Ingredient (\%) } & \multicolumn{4}{|c|}{ Experimental diet } \\
\hline & Control & $20 \mathrm{mg} \mathrm{FB} / \mathrm{kg}$ & $40 \mathrm{mg} \mathrm{FB} / \mathrm{kg}$ & $60 \mathrm{mg} \mathrm{FB} / \mathrm{kg}$ \\
\hline Soybean & 53.7 & 53.7 & 53.7 & 53.7 \\
\hline Corn & 31.0 & 31.0 & 31.0 & 31.0 \\
\hline Corn gluten 60 & 8.2 & 8.2 & 8.2 & 8.2 \\
\hline Soybean oil & 2.0 & 2.0 & 2.0 & 2.0 \\
\hline Corn starch & 1.0 & 1.0 & 1.0 & 1.0 \\
\hline DL-Methionine & 0.01 & 0.01 & 0.01 & 0.01 \\
\hline Calcitic limestone & 0.1 & 0.1 & 0.1 & 0.1 \\
\hline Dicalcium phosphate & 2.9 & 2.9 & 2.9 & 2.9 \\
\hline Vitamin $C^{a^{2}}$ & 0.06 & 0.06 & 0.06 & 0.06 \\
\hline $\begin{array}{l}\text { Mineral-vitamin } \\
\text { supplement }^{\mathrm{b}}\end{array}$ & 0.5 & 0.5 & 0.5 & 0.5 \\
\hline Common salt & 0.5 & 0.5 & 0.5 & 0.5 \\
\hline BHT (antioxidant) ${ }^{c}$ & 0.03 & 0.03 & 0.03 & 0.03 \\
\hline Fumonisin $\mathrm{B} 1+\mathrm{B} 2$ & - & 0.002 & 0.004 & 0.006 \\
\hline TOTAL & 100 & 100 & 100 & 100 \\
\hline \multicolumn{5}{|c|}{ Chemical composition of the diet $(\%)^{\mathrm{d}}$} \\
\hline Crude protein & 33.62 & 33.60 & 33.61 & 33.61 \\
\hline Dry matter & 89.52 & 89.51 & 89.50 & 89.52 \\
\hline Fat & 4.33 & 4.33 & 4.30 & 4.29 \\
\hline Ashes & 5.79 & 5.75 & 5.76 & 5.78 \\
\hline
\end{tabular}

${ }^{\text {a }}$ Vitamin C: calcium salt L-ascorbic acid 2-phosphate, $42 \%$ active ingredient.

b Mineral-vitamin supplement: Composition/kg of product: vit. A = 1200,000 IU; vit. $\mathrm{D} 3=200,000 \mathrm{IU}$; vit. $\mathrm{E}=12,000 \mathrm{mg}$; vit. $\mathrm{K} 3=2400 \mathrm{mg}$; vit. $\mathrm{B} 1=4.800 \mathrm{mg}$; vit. $\mathrm{B} 2=4800 \mathrm{mg}$; vit. $\mathrm{B} 6=4000 \mathrm{mg}$; vit. $\mathrm{B} 12=4800 \mathrm{mg}$; folic acid $=1200 \mathrm{mg}$; calcium pantothenate $=12,000 \mathrm{mg}$; vit. $\mathrm{C}=48,000 \mathrm{mg}$; biotin $=48 \mathrm{mg}$; choline $=65,000 \mathrm{mg}$; nicotinic $\quad$ acid $=24,000 \mathrm{mg} ; \quad \mathrm{Fe}=10,000 \mathrm{mg} ; \quad \mathrm{Cu}=600 \mathrm{mg} ; \quad \mathrm{Mn}=4000 \mathrm{mg}$; $\mathrm{Zn}=6000 \mathrm{mg} ; \mathrm{I}=20 \mathrm{mg} ; \mathrm{Co}=2 \mathrm{mg}$; and $\mathrm{Se}=20 \mathrm{mg}$

${ }^{\mathrm{c}}$ Butylated hydroxytoluene (Antioxidant).

${ }^{\mathrm{d}}$ Composition on a fresh matter basis.

separate layers. During this stage, $500 \mu \mathrm{L}$ of aqueous phase were collected and transferred to a clean tube containing $500 \mu \mathrm{L}$ of isopropanol. Tubes were homogenized and centrifuged for $15 \mathrm{~min}$ at $12,000 \mathrm{rpm}$ and $4{ }^{\circ} \mathrm{C}$. Supernatant was discarded, while $1 \mathrm{~mL}$ of $75 \%$ ethanol was added to the precipitate for cleaning. Tubes were centrifuged once again at $12,000 \mathrm{rpm}$ for $5 \mathrm{~min}$, and supernatant was discarded. Pellet was then dried for $15 \mathrm{~min}$ at $4{ }^{\circ} \mathrm{C}$ and resuspended in RNase-free ultrapure water.

Total RNA concentration was measured in a spectrophotometer at $260 \mathrm{~nm}$ wavelength. RNA integrity was evaluated using agarose gel stained $1.5 \%$ with ethidium bromide (10\%) and visualized under ultraviolet light. RNA samples were treated with DNase I (Invitrogen, Carlsbad, CA, USA), in accordance with the instructions of manufacturer to remove possible contaminations with genomic DNA.

SuperScript $^{\mathrm{TM}}$ III First-Strand Synthesis Super Mix kit (Invitrogen Corporation, Brazil) was used for cDNA synthesis according to the manufacturer's instructions. In this stage, $6 \mu \mathrm{L}$ of total RNA, $1 \mu \mathrm{L}$ of oligo dT ( $50 \mu \mathrm{M}$ oligo (dT) 20 ), and $1 \mu \mathrm{L}$ of annealing buffer were added to a RNA-free sterile tube. Tubes were incubated for $5 \mathrm{~min}$ at $65^{\circ} \mathrm{C}$ and immediately placed on ice for $1 \mathrm{~min}$. Next, $10 \mu \mathrm{L} 2 \times$ First-Strand Reaction Mix and $2 \mu \mathrm{L}$ of a solution containing SuperScript ${ }^{\mathrm{TM}}$ III reverse transcriptase enzyme were added to the tubes. The resulting solution was incubated for $50 \mathrm{~min}$ at $50^{\circ} \mathrm{C}$ and for $5 \mathrm{~min}$ at $85^{\circ} \mathrm{C}$, then immediately placed on ice. After this stage, samples were stored at $-20^{\circ} \mathrm{C}$ until their use.

Real-time PCR analyses were performed using the SYBR Green fluorescent dye (SYBR ${ }^{\circledR}$ GREEN PCR Master Mix, Applied Biosystems, USA).

Primers utilized for evaluation of caspase 7 (CASP7) and sphingosine phosphate lyase (SPL) genes were designed based on the sequences of genes stored at www.ncbi.nlm.nih.gov (access numbers XM_005471473 and XM_003441226.2, respectively), available through the website www.idtdna.com. Three endogenous controls obtained from Yang et al. (2013) were tested: UBCE (ubiquitin-conjugating
Table 2

Sequence of primers used for the real-time PCR reactions.

\begin{tabular}{lll}
\hline Primer & Sequence $\left(5^{\prime}-3^{\prime}\right)$ & Amplicon (bp) \\
\hline CASP7 $-\mathrm{F}$ & GATTCCCTGTGTGGTCTCTATG & 94 \\
CASP7 $-\mathrm{R}$ & GGTCAGTCTGTGGCATCATTA & \multirow{2}{*}{125} \\
SPL F & GTCACTGACCAAACTCCTAGTG & \\
SPL R & GACAACCTCTGCTTCCATCTT & 250 \\
EF1- $\alpha-\mathrm{F}$ & GCACGCTCTGCTGGCCTTT & \multirow{2}{*}{130} \\
EF1- $\alpha-\mathrm{R}$ & GCGCTCAATCTTCCATCCC & 217 \\
UBCE $-\mathrm{F}$ & CTCTCAAATCAATGCCACTTCC & \\
UBCE $-\mathrm{R}$ & CCCTGGTGGAGGTTCCTTGT & \\
BACT $-\mathrm{F}$ & TGGTGGGTATGGGTCAGAAAG & \\
BACT $-\mathrm{R}$ & TGTTGGCTTTGGGGTTCA & \\
\hline
\end{tabular}

enzyme - XM_003460024), EF1A (elongation factor1 $\alpha$ - AB075952), and ACTB ( $\beta$ actin - XM_003455949). Of these, ACTB was selected, as it showed the best efficiency (between 90 and 110\%) and did not vary statistically between the treatments. Primers utilized in this experiment are shown in Table 2.

All reactions were performed in the final volume of $12.5 \mu \mathrm{L}$, as well as in duplicates. Analysis of dissociation curves did not reveal any presence of primer dimers or non-specific products.

\subsection{Statistical analysis}

To evaluate relative expression, real-time PCR analysis data were transformed using $2^{-\Delta \mathrm{CT}}$, as demonstrated by Livak and Schmittgen (2001). Gene expression data were evaluated using a completely randomized design in a $2 \times 4$ factorial arrangement (two ages and four levels of fumonisin inclusion), employing GLM procedure, and mean values were compared by Tukey's test $(P<.05)$ (SAS Inst. Inc., Cary, NC, USA). Results were expressed as means and standard deviations. Data on ratio between mRNA expressions of SPL and CASP7 were analyzed using REG statement (SAS Inst. Inc., Cary, NC, USA).

\section{Results}

Mean values and standard deviations for relative expression ofCASP7 and SPL genes in liver of Nile tilapia fingerlings according to level of inclusion of fumonisin and period of consumption are shown in Table 3.

Gene expression of SPL enzyme was significantly changed by diets. An interaction effect between period of consumption and levels of fumonisin in diet (Fig. 2) was detected. Relative SPL mRNA levels were reduced only in tilapia treated with the $60 \mathrm{mg} \mathrm{FB} / \mathrm{kg}$ diet at 15 days $(P<.0001)$, whereas at 30 days, SPL had a significant increase in case of the two highest levels of inclusion $(P<.0001)$.

Gene expression for CASP7 was also significantly changed by diets, with the presence of a significant effect between period of consumption and levels of fumonisin (Fig. 3). At 15 days of treatment, inclusion of increasing levels of fumonisin reduced relative values of CASP7 mRNA in a linear manner $(P<.0001)$. At 30 days, the relative CASP7 mRNA levels were only reduced in tilapia treated with the $60 \mathrm{mg} \mathrm{FB} / \mathrm{kg}$ diet $(P=.0011)$.

A greater expression of CASP7 mRNA as compared with SPL was observed for control treatment both at 15 and 30 days. Paradoxically, SPL mRNA levels were higher than those of CASP7 for the two highest levels of fumonisin tested, as demonstrated in Fig. 4.

When the numerical relationship between relative expressions of SPL and CASP7 was evaluated, a strong upward trend was observed for this ratio as a function of the period and levels of fumonisin inclusion (Fig. 5). 
Table 3

Relative gene expression of the CASP7 and SPL genes at 15 and 30 days of ingestion of increasing levels of fumonisin.

\begin{tabular}{|c|c|c|c|c|}
\hline \multirow[t]{2}{*}{ Treatment } & \multicolumn{2}{|c|}{ CASP7 (mRNA) AU } & \multicolumn{2}{|l|}{ SPL (mRNA) AU } \\
\hline & 15 days & 30 days & 15 days & 30 days \\
\hline Control & $0.023 \pm 0.01$ & $0.0025 \pm 0.0004$ & $0.0051 \pm 0.0003$ & $0.0015 \pm 0.0003$ \\
\hline $20 \mathrm{mg} \mathrm{FB} / \mathrm{kg}$ & $0.011 \pm 0.0023$ & $0.0024 \pm 0.0006$ & $0.0045 \pm 0.0006$ & $0.0013 \pm 0.0001$ \\
\hline $40 \mathrm{mg} \mathrm{FB} / \mathrm{kg}$ & $0.004 \pm 0.0014$ & $0.0022 \pm 0.0001$ & $0.0044 \pm 0.0009$ & $0.0034 \pm 0.0010$ \\
\hline $60 \mathrm{mg} \mathrm{FB} / \mathrm{kg}$ & $0.001 \pm 0.0005$ & $0.0007 \pm 0.0001$ & $0.0023 \pm 0.0003$ & $0.0023 \pm 0.0006$ \\
\hline
\end{tabular}

${ }^{\mathrm{a}} \mathrm{AU}$ - arbitrary units.
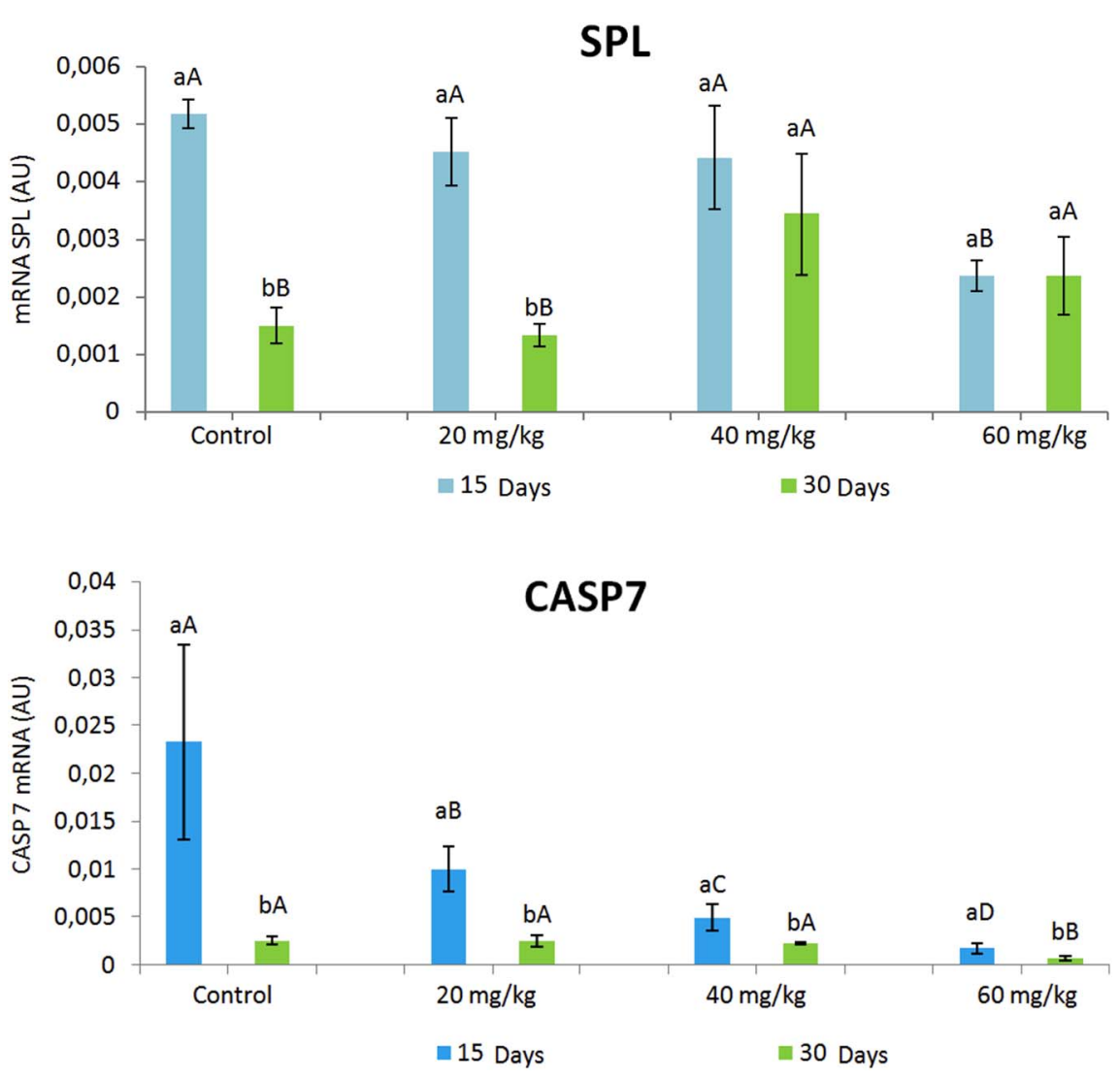

Fig. 2. Effects of period of consumption and levels of inclusion of fumonisin on the gene expression of SPL. Values are expressed in arbitrary units (AU). Lowercase letters on the bars compare the means between periods in the same treatment. Uppercase letters on the bars represent the test of means between the levels in the same period. Tukey's test at $5 \%$ probability.

\section{Discussion}

In this study, we evaluated gene expression of SPL and caspase 7 (CASP7) enzymes. For SPL, an effect of interaction between concentrations of fumonisin and days of exposure to the toxin $(P<.0001)$ was observed, suggesting that the effects of fumonisin are dose-timedependent. At 15 days, different levels of fumonisin affected mRNA expression of SPL $(P=.0002)$, with a slight reduction of this expression only for animals that consumed diet with the highest level of fumonisin inclusion. On the other hand, in animals fed for 30 days, a significant increase in expression of SPL was discovered at the two highest tested levels of fumonisin inclusion $(P<.0001)$ (Fig. 2).

S1P levels in cells are strongly regulated by the balance between its synthesis and degradation. It is possible that the response of gene expression of SPL enzyme at 15 days results from the activation of compensatory mechanism, in which the Sa/So-1-phosphate phosphatase enzyme (S1PP), which catalyzes return of sphingosine 1-phosphate to sphingosine, prevented accumulation of S1P, especially at the highest level of fumonisin inclusion, in an unsuccessful attempt to form ceramide via ceramide synthase.

At 30 days, an increase in SPL expression was observed. A longer duration of fumonisin exposure likely affected ceramide synthase, promoting accumulation of sphingoid bases and consequently an increase in the production of S1P and SPL expression, as suggested by Loetscher et al. (2013). Also, biochemical signals observed with consumption of fumonisin, like Sa/Sa ratio, concentration of ceramide, and concentration of macromolecules involved in this pathway are timeand dose-dependent, corroborating the differences observed at 15 and 30 days of testing (Wang et al., 1992). There is a threshold between cell behavior that leads to apoptosis or proliferation. Huang et al. (2011) suggested a model called "sphingolipid rheostat", in which the ceramide/sphingosine and S1P levels, which have opposing functions, are interchangeable within cells and may lead to cell death (when the balance is shifted towards ceramide/sphingosine) or survival and proliferation (when S1P levels are increased) (Fig. 6).

Thus, it is possible that the increase in levels of SPL observed at 30 days is an attempt of the body to reduce cell proliferation rate through irreversible catalysis of S1P. It is believed that SPL has the ability to change cell balance by its direct action on S1P levels, involving p53 and p38MAPK signaling pathways, which are associated with the signaling of cell death involving the caspases (Giovannini et al., 2011).

Some studies have identified fumonisins as stimulators of apoptosis via caspase (Kim et al., 2007; Gopee and Sharma, 2004); nevertheless, 

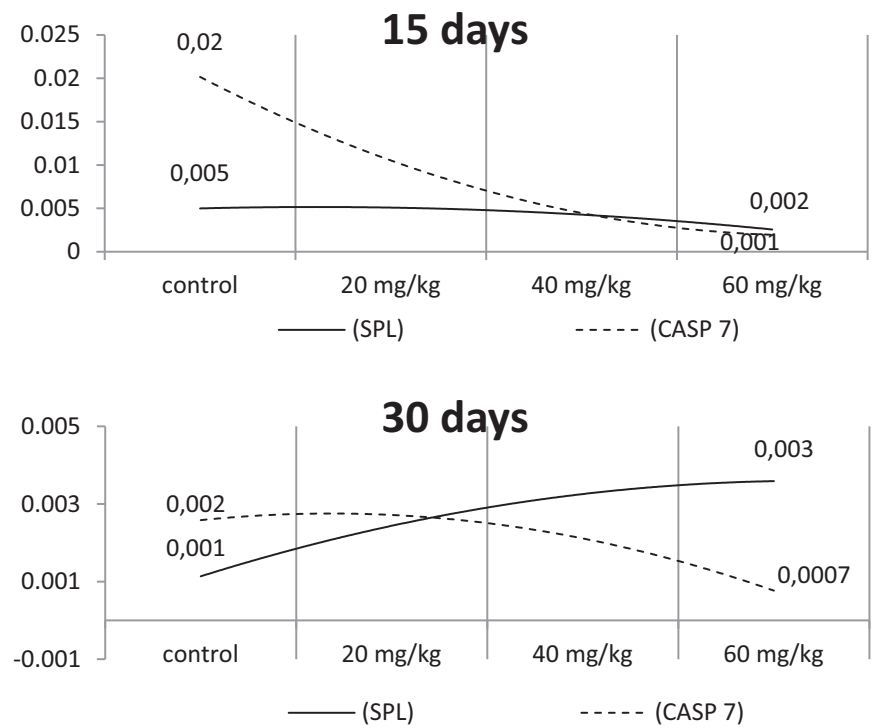

Fig. 4. Comparison between the expression pattern of SPL and CASP7 mRNA at 15 and 30 days of treatment.

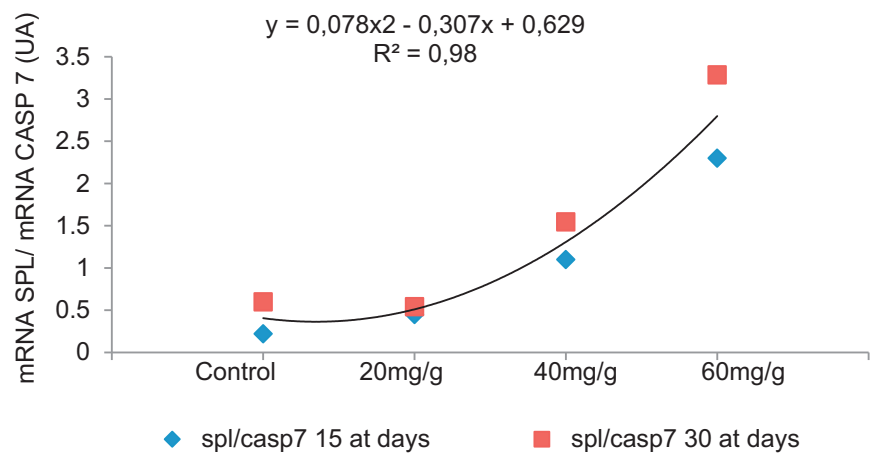

Fig. 5. Numerical relationship between the SPL and CASP7 mRNA levels in the liver of Nile tilapia challenged with increasing levels of fumonisin for 15 and 30 days.

the findings of this study suggest a different response. In the present experiment, fish subjected to increasing levels of fumonisin for 15 days showed a marked reduction of CASP7 mRNA (approximately 23 times). At 30 days of treatment, a reduction in CASP7 expression was also observed, but to a lesser extent (approximately 3.5 times) (Table 3). Overall, the resulting data demonstrates that inclusion of increasing levels of fumonisin reduces caspase 7 mRNA expression in liver of Nile tilapia. Similarly to our findings, Mullen et al. (2012) observed that inhibition of ceramide synthase by fumonisins also inhibited activation of caspases 3 and 7, with a subsequent decrease in apoptosis, suggesting that the roles of ceramide affect activation of caspase directly by influencing permeability of external mitochondrial membrane, preventing mobilization of factors responsible for the onset of the caspase cascade.
In cells under normal conditions, there is an accumulation of intracellular ceramide after receiving genotoxic stimuli that acts directly on protein phosphatase 2 (PP2A) (Xin and Deng, 2006; Bionda et al., 2004). This phosphatase, together with anti-apoptotic Akt/PKB kinase, regulates the action of anti-apoptotic factors Bax/Bcl-2, promoting mitochondrial permeability (Taha et al., 2006). Subsequently, protein "Smac/DIABLO" and cytochrome c are released by the mitochondria, promoting activation of caspase cascade through the adapter protein Apaf-1 (Du et al., 2000). Boppana et al. (2014) demonstrated in their study that fumonisin plays an anti-apoptotic role by inhibiting accumulation of ceramide in endoplasmic reticulum, Bax translocation to mitochondria, and release of cytochrome $\mathrm{c}$.

In this context, lower concentrations of ceramide resulting from consumption of fumonisin may be responsible for lower CASP7 expression observed in the present study and consequent reduction of caspase-dependent apoptosis rates. Our study suggests that fumonisin plays an anti-apoptotic role by means of expressive reduction of CASP7.

When SPL and CASP7 expressions for proposed levels of inclusion were evaluated synergistically, we could observe that a gene-expression pattern occurred, in which the control treatment resulted in higher CASP7 levels than SPL, while at the highest level of inclusion of fumonisin this response was the opposite, with a higher SPL expression than CASP7 (Fig. 4). Inversion of expression of these genes was more marked at 30 days. Kim et al. (2007) also observed an inverse pattern of expression for SPL and caspase 3 in liver of rats exposed to fumonisin; however, the lowest expression of caspase and the highest SPL expression were observed in animals subjected to control treatment.

In this study inverse patterns of expression for CASP7 and SPL were observed according to levels of fumonisin, so we also evaluated response shown by ratio between these genes. While analyzing this ratio, we observed an upward trend in this value as a response to increasing levels of fumonisin in diets (Fig. 5). Thus, it can be assumed that the mechanisms involved in increase of the SPL expression are also related to reduction of CASP7 expression, when animals consume a ceramide suppressant.

Overall, our results indicate alterations in SPL expression of tilapia fingerlings consuming increasing doses of fumonisin in diet and that the effects are dose- and time-dependent. It is likely that the observed reduction in CASP7 mRNA levels is dependent on the reduction in ceramide levels (Reiss et al., 2004), which were probably changed as a result of fumonisin action. The increase in SPL is probably the result of an increased number of sphingoid bases, and consequently of S1P. These results demonstrate a direct relationship between SPL and CASP7 expressions, so it can be inferred that as the time consuming fumonisin is increased, the numerical relationship between of SPL and CASP7 gene expressions will also increase.

\section{Conclusion}

Consumption of feed containing increasing levels of mycotoxin fumonisin B1 + B2 affects expression of genes involved in apoptotic balance, caspase 7 and sphingosine phosphate lyase, according to the period of ingestion.
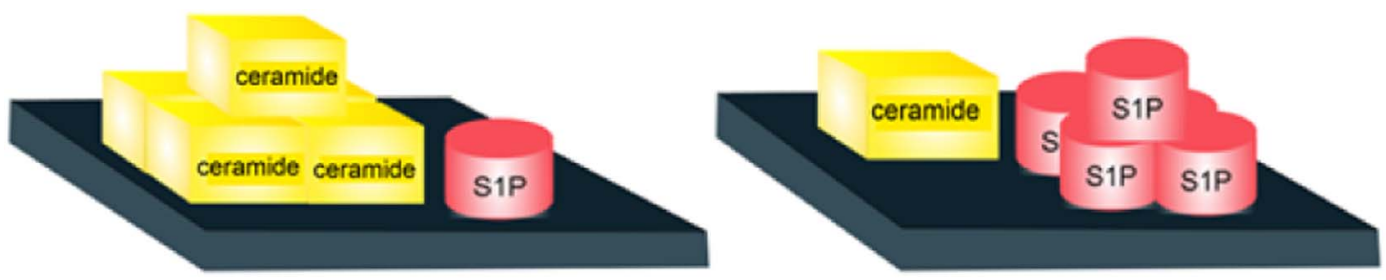

More apoptosis and cell cycle blockage

Greater cell proliferation

Fig. 6. Relationship between ceramide and S1P. Adapted from Huang et al. (2011). 


\section{Conflict of interest}

The authors declare that they have no conflict of interest.

\section{References}

Bionda, C., Portoukalian, J., Schmitt, D., Rodriguez-Lafrasse, C., Ardail, D., 2004. Subcellular compartmentalization of ceramide metabolism: MAM (mitochondria-associated membrane) and/or mitochondria? Biochem. J. 382, 527-533. http://dx.doi. org/10.1042/BJ20031819.

Biswal, S.S., Datta, k., Acquaah-Mensahg, K., Kehrerj, P., 2000. Changes in ceramide and sphingomyelin following fludarabine treatment of human chronic B-cell leukemia cells. Toxicology 154, 45-53. http://dx.doi.org/10.1016/S0300-483X(00)00296-1.

Boppana, N.B., Kodiha, M., Stochaj, U., Lin, H.S., Haimovitz-Friedman, A., Bielawska, A., Bielawski, J., Divine, G.W., Boyd, J.A., Korbelik, M., Separovic, D., 2014. Ceramide synthase inhibitor fumonisin B1 inhibits apoptotic cell death in SCC17B human head and neck squamous carcinoma cells after Pc4 photosensitization. Photochem. Photobiol. Sci. 15 (13(11)), 1621-1627. http://dx.doi.org/10.1039/c4pp00292j.

Bose, R., Verheij, M., Haimovitz-Friedman, A., Scotto, K., Fuks, Z., Kolesnick, R., 1995. Ceramide synthase mediates daunorubicin-induced apoptosis: an alternative mechanism for generating death signals. Cell 82, 405-414. http://dx.doi.org/10.1016/ 0092-8674(95)90429-8.

Du, C., Fang, M., Li, Y., Li, L., Wang, X., 2000. Smac, a mitochondrial protein that promotes cytochrome c-dependent caspase activation by eliminating IAP inhibition. Cell 102, 33-42. http://dx.doi.org/10.1016/S0092-8674(00)00008-8.

Ferreira, A.K., Meneguelo, R., Pereira, A., Filho, O.M., Chierice, G.O., Maria, D.A., 2013. Synthetic phosphoethanolamine induces cell cycle arrest and apoptosis in human breast cancer MCF-7 cells through the mitochondrial pathway. Biomed Pharmacother 67 (6), 481-487. http://dx.doi.org/10.1016/j.biopha.2013.01.012.

Gbore, F.A., Adewole, A.M., Oginni, O., Oguntolu, M.F., Bada, A.M., Akele, O., 2010 Growth performance, haematology and serum biochemistry of African catfish (Clariasgariepinus) fingerlings fed graded levels of dietary fumonisin B1. Mycotoxin Res. 26 (4), 221-227. http://dx.doi.org/10.1007/s12550-010-0059-2.

Giovannini, C., Varì, R., Scazzocchio, B., Sanchez, M., Santangelo, C., Filesi, C., D'archivio, M., Masella, R., 2011. OxLDL induced p53-dependent apoptosis by activating p38MAPK and PKC? Signaling pathways in J774A.1 macrophage cells. J. Mol. Cell Biol. 3 (5), 316-318. http://dx.doi.org/10.1093/jmcb/mjr019.

Goel, S., Lens, S.D., Lumlertdacha, S., Lovell, R.T., Shelby, R.A., Li, M., Riley, R.T., Kemppainen, B.W., 1994. Sphingolipid levels in catfish consuming F. moniliforme corn culture material with fumonisins. Aquat. Toxicol. 30, 285-294.

Gopee, N.V., Sharma, R.P., 2004. The mycotoxin fumonisin B1 transiently activates nuclear factor-kappaB, tumor necrosis factor alpha and caspase 3 via protein kinase Calpha-dependent pathway in porcine renal epithelial cells. Cell Biol. Toxicol. 20 (4), 197-212.

Griessler, K., Encarnação, P., 2009. Fumonisins - mycotoxins of increasing importance in fish. In: Aquaculture Asia Magazine. XIV (2). pp. 24-26.

Huang, Y.L., Huang, W.P., Lee, H., 2011. Roles of sphingosine 1-phosphate on tumorigenesis. World J. Biol. Chem. 26 (2(2)), 25-34. http://dx.doi.org/10.4331/wjbc.v2. i2.25.

Jones, C., Ciacci-Zanella, J.R., Zhang, Y., Henderson, G., Dickman, M., 2001. Analysis of fumonisin B1-induced apoptosis. Environ. Health Perspect. 109 (2), 315-320.

Kim, D.H., Lee, Y.S., Lee, Y.M., Oh, S., Yun, Y.P., Yoo, W.S., 2007. Elevation of sphingoid base 1-phosphate as a potential contributor to hepatotoxicity in fumonisin B1-exposed mice. Arch. Pharm. Res. 30 (8), 962-969.

Kovačić, S., Pepeljnjak, S., Petrinec, Z., Klarić, M.S., 2009. Fumonisin B1 neurotoxicity in young carp (Cyprinuscarpio l.). Arh. Hig. Rada Toksikol. 60, 419-426. http://dx.doi. org/10.2478/10004-1254-60-2009-1974.

Livak, K.J., Schmittgen, T.D., 2001. Analysis of relative gene expression data using realtime quantitative PCR and the 2(-Delta Delta C(T)). Methods 25 (4), 402-408. http://dx.doi.org/10.1006/meth.2001.1262.

Loetscher, E., Schneider, K., Beerli, C., Billich, A., 2013. Assay to measure the secretion of sphingosine-1-phosphate from cells induced by S1P lyase inhibitors. Biochem. Biophys. Res. Commun. 12 (433(3)), 345-348. http://dx.doi.org/10.1016/j.bbrc. 2013.03.004.

Lumlertdacha, S., Lovell, R.T., Shelbyb, R.A., Lenz', S.D., Kemppainen, B.W., 1995. Growth, hematology, and histopathology of channel catfish, Ictalurus punctatus, fed toxins from Fusarium moniliforme. Aquaculture 130, 201-218. http://dx.doi.org/10. 1016/0044-8486(94)00219-E.

Mullen, T.D., Jenkins, R.W., Clarke, C.J., Bielawski, J., Hannun, Y.A., Obeid, L.M., 2011. Ceramide synthase-dependent ceramide generation and programmed cell death: involvement of salvage pathway in regulating postmitochondrial events. J. Biol. Chem 286, 15929-15942. http://dx.doi.org/10.1074/jbc.M111.230870.

Mullen, T.D., Hannuny, A., Obeidl, M., 2012. Ceramide synthases at the centre of sphingolipid metabolism and biology. Biochem. J. 441 (3), 789-802. http://dx.doi. org/10.1042/BJ20111626.

Pepeljnjak, S., Petrinec, Kovacic, S., Segvic, M., 2002. Screening toxicity study in young carp (Cyprinuscarpio L.) on feed amended with fumonisin B1. Mycopathologia 156, 139-145.

Reiss, U., Oskouian, B., Zhou, J., Gupta, V., Sooriyakumaran, P., Kelly, S., Wang, E., Merrill Jr., A.H., Saba, J.D., 2004. Sphingosine-phosphate lyase enhances stress-induced ceramide generation and apoptosis. J. Biol. Chem. 279 (2), 1281-1290. http:// dx.doi.org/10.1074/jbc.M309646200.

Ribeiro, D.H.B., Ferreira, F.L., da Silva, V.N., Aquino, S., Corrêa, B., 2010. Effects of aflatoxin B1 and Fumonisin B1 on the viability and induction of apoptosis in rat primary hepatocytes. Int. J. Mol. Sci. 11 (4), 1944-1955. http://dx.doi.org/10.3390/ ijms11041944.

Riley, R.T., Voss, K.A., 2006. Differential sensitivity of rat kidney and liver to Fumonisin toxicity: organ-specific differences in toxin accumulation and Sphingoid Base metabolism. Toxicol. Sci. 92 (1), 335-345. http://dx.doi.org/10.1093/toxsci/kfj198.

Spiegel, S., Merrill Jr., A.H., 1996. Sphingolipid metabolism and cell growth regulation. FASEB J. 10 (12), 1388-1397.

Taha, T.A., Mullen, T.D., Obeid, L.M., 2006. A house divided: ceramide, sphingosine, and sphingosine-1-phosphate in programmed cell death. Biochim. Biophys. Acta 1758 (12), 2027-2036. http://dx.doi.org/10.1016/j.bbamem.2006.10.018.

Tuan, N.A., Manning, B.B., Lovell, R.T., Rottinghaus, G.E., 2003. Responses of Nile tilapia (Oreochromis niloticus) fed diets containing different concentrations of moniliformin or fumonisin B1. Aquaculture 217, 515-528. http://dx.doi.org/10.1016/S0044 8486(02)00268-5.

Turner, P.C., Nikiema, P., Wild, C.P., 1999. Fumonisin contamination of food: progress in development of biomarkers to better assess human health risks. Mutat. Res. 443, 81-93. http://dx.doi.org/10.1016/S1383-5742(99)00012-5.

Wang, E., Norred, W.P., Bacon, C.W., Riley, R.T., Merrill Jr., A.H., 1991. Inhibition of sphingolipid biosynthesis by fumonisins. Implications for diseases associated with Fusarium moniliforme. J. Biol. Chem. 5 (266(22)), 14486-14490.

Wang, E., Ross, P.F., Wilson, T.M., Riley, R.T., Merrill Jr., A.H., 1992. Increases in serum sphingosine and sphinganine and decreases in complex sphingolipids in ponies given feed containing fumonisins, mycotoxins produced by Fusarium moniliforme. J. Nutr. $122,1706-1716$

Xin, M., Deng, X., 2006. Protein phosphatase 2A enhances the proapoptotic function of Bax through dephosphorylation. J. Biol. Chem. 7 (281(27)), 18859-18867. http://dx. doi.org/10.1074/jbc.M512543200.

Yang, C.G., Wang, X.L., Tian, J., Liu, W., Wu, F., Jiang, M., Wen, H., 2013. Evaluation of reference genes for quantitative real-time RT-PCR analysisof gene expression in Nile tilapia (Oreochromis niloticus). Gene 527, 183-192. http://dx.doi.org/10.1016/j.gene. 2013.06.013.

Yoo, H., Norred, W.P., Wang, E., Merrill Jr., A.H., Riley, R.T., 1992. Fumonisin inhibition of de novo sphingolipid biosynthesis and cytotoxicity are correlated in LLC-PKX cells. Toxicol. Appl. Pharmacol. 114, 9-15. 